\title{
Hubungan kebiasaan buruk postur tubuh dengan bunyi kliking sendi temporomandibula
}

\author{
Kamila Washfanabila $^{1 *}$, Rasmi Rikmasari ${ }^{1}{ }^{1}$ Aprillia Adenan $^{1}$ \\ ${ }^{1}$ Departemen Prostodonsia, Fakultas Kedokteran Gigi Universitas Padjadjaran, Indonesia \\ *Korespondensi: kamila14001@mail.unpad,ac.id.
}

\begin{abstract}
ABSTRAK
Pendahuluan: Kebiasaan buruk postur tubuh merupakan suatu kebiasaan posisi tubuh yang menyimpang dari posisi normal. Kebiasaan buruk postur tubuh ini mengakibatkan perubahan pada komponen sistem muskuloskeletal dan dalam jangka waktu yang lama dapat menyebabkan ketidakseimbangan pada sistem tersebut. Sendi temporomandibula memiliki hubungan dengan regio servikal membentuk suatu sistem "kranioserviko-mandibula". Gangguan pada kranioservikomandibula yang berdampak pada postur tubuh biasanya adalah gangguan pada sendi temporomandibula. Salah satu gejala dari gangguan sendi temporomandibula adalah adanya bunyi kliking. Tujuan dari penelitian ini adalah untuk mengetahui ada atau tidaknya hubungan antara kebiasaan buruk postur tubuh dengan bunyi kliking sendi temporomandibula. Metode: Jenis penelitian adalah deskriptif dengan pengamatan yang dilakukan secara cross-sectional pada mahasiswa Fakultas Kedokteran Gigi Universitas Padjadjaran angkatan 2014. Sampel penelitian dipilih dengan metode purposive sampling.Penelitian dilakukan pada 71 mahasiswa Fakultas Kedokteran Gigi Universitas Padjadjaran dengan memberikan kuesioner mengenai kebiasaan buruk postur tubuh dan pemeriksaan bunyi kliking pada sendi temporomandibula. Hasil: terdapat hubungan yang signifikan antara kebiasaan buruk postur tubuh dengan bunyi kliking pada sendi temporomandibula dengan keterkaitan sebesar 8,45\%. Kebiasaan buruk postur tubuh yang paling sering dilakukan oleh mahasiswa Fakultas Kedokteran Gigi Universitas Padjadjaran adalah menunduk saat menggunakan ponsel dengan persentasi sebanyak 63 orang. Simpulan: pasien dengan kebiasaan buruk postur tubuh dapat mengalami gangguan pada sendi temporomandibula dengan gejala berupa bunyi kliking.
\end{abstract}

Kata kunci: Kebiasaan buruk, postur tubuh, bunyi kliking sendi temporomandibula

\section{Correlation between bad posture habits and clicking sound on temporomandibular joint at students of faculty of dentistry padjadjaran university}

\begin{abstract}
Introduction: Bad posture habits are a habit of body position that deviates from the normal position which result in changes in the musculoskeletal system components and over a long period of time can cause an imbalance in the system. Disorders of the temporomandibular joint are one of the disorders of the musculoskeletal system. One symptom of temporomandibular joint disorder is the presence of clicking sounds. The purpose of this study is to explaine a relationship between bad posture habits with clicking sounds joints temporomandibula. Methode: This research uses descriptive observational method with cross sectional approach. The study was conducted on 71 students of Dentistry Faculty of Padjadjaran University by giving questionnaires about bad posture habits and checking of clicking sounds on temporomandibula joints using stethoscope. The data obtained were analyzed using Spearman's Rank correlation test. Results: there was a significant association between FHP, sitting habits with chin rest, sitting habits and slouching in a chair, head resting on a table, carrying bags on one side, standing on one leg, and a stomach posture position with a sound click on the temporomandibular joint. While the habit of sleeping with pillows that are too high, standing with a flat back, hunching over while using the phone, and cross-legged sitting do not have a significant relationship with clicking sounds on the joints temporomandibula. Conclusions: There is a significant relationship between bad posture habits with clicking sounds on temporomandibular joints with a linkage of $8.45 \%$ and patients with poor postural habits may suffer from temporomandibular joints disorders with symptoms of clicking.
\end{abstract}

Keywords: Bad habits, clicking sounds on temporomandibular joint, posture 


\section{PENDAHULUAN}

Sistem stomatognatik merupakan sistem yang bertanggung jawab terhadap fungsi pengunyahan, penelanan, dan bicara. Sistem stomatognatik terdiri dari tiga organ utama, yaitu sendi temporomandibula, otot pengunyahan, dan gigi geligi beserta struktur pendukungnya yang berfungsi secara harmonis dan dikoordinasikan oleh sistem saraf pusat. ${ }^{1}$ Disharmoni dari sistem stomatognatik dapat disebabkan oleh beberapa hal, seperti kebiasaan buruk postur tubuh yang dilakukan dalam aktivitas sehari-hari. Tanpa disadari kebiasaan buruk tersebut menyebabkan ketidakseimbangan posisi tulang dan fungsi otot, bila berlangsung terus-menerus dapat merubah postur tubuh secara permanen. ${ }^{2}$ Posisi dan postur tubuh yang salah mengakibatkan komponen neuromuskular mengalami ketidaknyamanan dan ketidaklancaran dalam setiap pergerakan. ${ }^{3}$

Kesalahan postur tubuh yang berkelanjutan dapat berdampak pada segi kesehatan, penampilan, dan psikologis. Seseorang dengan posisi tubuh yang buruk sangat berpotensi mempercepat timbulnya kelelahan dan nyeri pada otot. Jika keadaan tersebut berlangsung setiap hari dengan durasi yang lama maka akan terjadi kerusakan otot, sendi, tendon, ligamen, dan jaringan-jaringan disekitarnya yang memicu terjadinya gangguan sistem muskuloskeletal. ${ }^{4}$ Kesalahan postur tubuh akan mempengaruhi posisi kepala dan leher, yaitu kesalahan tersebut bisa menyebabkan terjadinya gangguan pada sendi temporomandibula. Gangguan sendi temporomandibula adalah sekumpulan gejala klinik yang melibatkan otot-otot pengunyahan, sendi temporomandibula, atau kedua-duanya. Gejala utamanya adalah nyeri pada kepala dan leher, adanya bunyi sendi, keterbatasan buka mulut, dan deviasi pada saat buka mulut. ${ }^{5}$ Tujuan dari penelitian ini adalah untuk mengetahui ada atau tidaknya hubungan antara kebiasaan buruk postur tubuh dengan bunyi kliking sendi temporomandibular. Hasil penelitian diharapkan dapat bermanfaat agar mahasiswa Fakultas Kedokteran Gigi Universitas Padjadjaran dapat memperbaiki kesalahan postur tersebut.

\section{METODE}

Jenis penelitian adalah deskriptif dengan pengamatan yang dilakukan secara cross-sectional pada mahasiswa Fakultas Kedokteran Gigi Universitas Padjadjaran angkatan 2014. Sampel penelitian dipilih dengan metode purposive sampling. Kriteria pemilihan sampel pada penelitian ini adalah (1) Tidak memiliki kelainan muskuloskeletal seperti lordosis, kifosis, dan skoliosis; (2) Tidak sedang dalam perawatan ortodonti cekat atau lepasan; (3) Tidak pernah mengalami trauma atau fraktur sendi temporomandibula; (4) Tidak mempunyai kebiasaan buruk parafungsi seperti bruxism, clenching, gnashing, dan grinding. Data dan informasi dikumpulkan dari responden dengan menggunakan kuesioner kebiasaan buruk postur tubuh dan pemeriksaan bunyi kliking pada sendi temporomandibula. Penelitian ini dilaksanakan di Kampus Fakultas Kedokteran Gigi Universitas Padjadjaran Jatinangor. Waktu penelitian dilakukan pada bulan November 2017 sampai Januari 2018. Data yang terkumpul diolah dan dianalisis menggunakan uji korelasi Spearman's Rank. Berdasarkan surat pembebasan etik No. 1217/UN6.C10/PN/2017 Komisi Etik Penelitian Kesehatan Fakultas Kedokteran Universitas Padjadjaran tanggal 13 Desember 2017.

\section{HASIL}

Penilaian kebiasaan buruk postur tubuh pada mahasiswa Fakultas Kedokteran Gigi Universitas Padjadjaran dilakukan dengan kuesioner kebiasaan buruk tersebut. Penilaian kebiasaan buruk ini dilakukan langsung setelah responden selesai mengisi kuesioner tersebut. Berdasarkan hasil dan penilaian kebiasaan buruk postur tubuh tersebut didapatkan data sebagai berikut.

Tabel 2 mendeskripsikan kebiasaan buruk postur tubuh mahasiswa Fakultas Kedokterdan Gigi Universitas Padjadjaran dimana terlihat bahwa responden berada di dalam kategori postur sedang. Penilaian bunyi kliking sendi temporomandibula pada mahasiswa Fakultas Kedokteran Gigi Universitas Padjadjaran dilakukan dengan pemeriksaan auskultasi pada bagian periaurikular dengan menggunakan stetoskop pada saat responden membuka dan menutup mulut. Penilaian dilakukan langsung setelah pemeriksaan tersebut.

Skala pengukuran yang digunakan pada variabel bebas adalah interval dan variabel terkait adalah nominal. Data tersebut dianalisis menggunakan uji korelasi Spearman's Rank yang digunakan pada perhitungan statistik non parametris. Hasil analisa kedua variabel tersebut adalah sebagai berikut: Pengujian korelasi statistik dari setiap kebiasaan buruk dapat dilihat pada tabel berikut: 
Tabel 1 menunjukkan kebiasaan buruk postur tubuh paling banyak adalah menunduk saat menggunakan handphone dan paling rendah adalah FHP dan posisi tidur dengan bantal tinggi

\begin{tabular}{ccc}
\hline No & Kebiasaan Buruk Postur Tubuh & Jumlah \\
\hline 1. & Berdiri dengan postur membungkuk & 42 \\
2. & Berdiri bertumpu pada satu kaki & 39 \\
3. & Forward Head Position & 16 \\
4. & Duduk membungkuk dan bermalas-malasan & 60 \\
5. & Duduk dengan menyilangkan kaki & 52 \\
6. & Menunduk saat menggunakan handphone & 63 \\
7. & Duduk menopang dagu & 42 \\
8. & Menyandarkan kepala pada meja & 36 \\
9. & Membawa tas berat pada satu sisi & 30 \\
10. & Tidur dengan posisi bantal terlalu tinggi & 16 \\
\hline
\end{tabular}

Tabel 2. Distribusi Skor Data Kebiasaan Buruk Postur Tubuh pada Mahasiswa Fakultas Kedokteran Gigi Universitas Padjadjaran

\begin{tabular}{cccc}
\hline Kategori & Nilai Skor & Jumlah & \% \\
\hline Postur Baik & 1 & 12 & 17 \\
Postur Sedang & 2 & 47 & 66 \\
Postur Buruk & 3 & 12 & 17 \\
\hline Total & & $\mathbf{7 1}$ & $\mathbf{1 0 0}$ \\
\hline
\end{tabular}

Tabel 3. Hasil Pemeriksaan Bunyi Kliking Sendi Temporomandibula pada Mahasiswa Fakultas Kedokteran Gigi Universitas

\begin{tabular}{ccc} 
& Padjadjaran & \\
\hline Hasil Pemeriksaan & Jumlah & \% \\
\hline Bunyi Kliking & 35 & 49 \\
Tidak Kliking & 36 & 51 \\
\hline Total & $\mathbf{7 1}$ & $\mathbf{1 0 0}$ \\
\hline
\end{tabular}

Tabel 4 Analisa Korelasi Spearman's Rank antara Kebiasaan Buruk Postur Tubuh dan Bunyi Kliking Sendi Temporomandibula pada Mahasiswa Fakultas Kedokteran Gigi Universitas Padjadjaran

\begin{tabular}{cccccc}
\hline Variabel & $\mathbf{r}_{\mathbf{s}}$ & t hitung & p-value & Keterangan & Keterkaitan \\
\hline Kebiasaan \& Kliking & 0,29 & 2,52 & 0,006954 & \multirow{2}{*}{ Sign } & 8,45 \\
\hline
\end{tabular}

Tabel 5 Analisa Korelasi Masing-Masing Kebiasaan Buruk Postur Tubuh dengan Bunyi Kliking Sendi Temporomandibula pada Mahasiswa Fakultas Kedokteran Gigi Universitas Padjadjaran

\begin{tabular}{ccccccc}
\hline Kebiasaan \& Kliking & $\mathbf{r}_{\mathbf{s}}$ & $\mathbf{n}$ & t hitung & p-value & Keterangan & Keterkaitan \\
\hline FHP & 0,64 & 16 & 3,11 & 0,00385161 & Sign & 40,83 \\
$\quad$ Duduk menopang dagu & 0,37 & 42 & 2,55 & 0,00740437 & Sign & 13,96 \\
$\begin{array}{l}\text { Berdiri bertumpu satu kaki } \\
\text { Duduk membungkuk dan }\end{array}$ & 0,36 & 39 & 2,36 & 0,0121235 & Sign & 12,98 \\
$\quad$ bermalas-malasan & 0,22 & 60 & 1,70 & 0,04710674 & Sign & 4,75 \\
$\quad \begin{array}{l}\text { Duduk bersandar pada } \\
\text { meja }\end{array}$ & 0,29 & 36 & 1,80 & 0,04053674 & Sign & 8,68 \\
$\begin{array}{l}\text { Membawa tas berat } \\
\text { pada satu sisi }\end{array}$ & 0,32 & 30 & 1,80 & 0,04128531 & Sign & 10,38 \\
$\begin{array}{l}\text { Beraktivitas dengan posisi } \\
\text { tengkurap }\end{array}$ & 0,31 & 44 & 2,10 & 0,0206756 & Sign & 9,54
\end{tabular}




\begin{tabular}{lcccccc}
\hline $\begin{array}{l}\text { Menunduk saat } \\
\text { menggunakan handphone }\end{array}$ & 0,21 & 63 & 1,64 & 0,05337681 & Non-Sign & 4,21 \\
$\begin{array}{l}\text { Duduk dengan kaki } \\
\text { menyilang }\end{array}$ & 0,22 & 52 & 1,61 & 0,05651079 & Non-Sign & 4,95 \\
$\begin{array}{l}\text { Berdiri membungkuk } \\
\begin{array}{l}\text { Tidur dengan bantal terlalu } \\
\text { tinggi }\end{array}\end{array}$ & 0,22 & 42 & 1,43 & 0,07954115 & Non-Sign & 4,90 \\
\hline
\end{tabular}

\section{PEMBAHASAN}

Responden yang memenuhi kriteria dalam penelitian ini berjumlah 71 orang. Jumlah responden yang berjenis kelamin perempuan 80,3\% dan laki-laki 19,7\%. Mayoritas responden pada penelitian ini adalah perempuan karena populasi mahasiswa Fakultas Kedokteran Gigi Universitas Padjadjaran sebagian besar adalah perempuan.

Pemeriksaan klinis pada 71 orang sampel pada penelitian ini, sampel yang mengeluhkan bunyi kliking pada sendi temporomandibula sebanyak 35 orang atau 49\%. Timbulnya bunyi pada sendi merupakan disfungsi TMJ yang dapat dibagi atas dua jenis, yaitu rubbing sound (krepitasi) dan clicking sound (kliking). ${ }^{6}$ Krepitasi adalah bunyi mengerat atau gemertak yang menunjukkan adanya jaringan degenerasi. Biasanya keadaan ini ditemukan pada pasien dengan kelainan sendi temporomandibula jangka panjang dan jarang terjadi pada usia muda. ${ }^{7}$

Kliking merupakan bunyi "klik" pada sendi yang dapat terjadi saat membuka atau menutup mulut dan ini disebut single click, sedangkan ada bunyi yang dirasakan terjadi saat membuka dan menutup mulut sehingga disebut reciprocal clicking. ${ }^{1}$ Pada kebanyakan kasus, suara kliking pada TMJ 70-80 \% disebabkan oleh disc displacement dengan berbagai tingkatan dan arah, tetapi sebagian besar pada arah anteromedial. ${ }^{6}$ Pada umumnya kliking terjadi selama gerak membuka mulut, tetapi juga bisa terjadi sesaat sebelum menutup mulut ketika diskus bergerak kebelakang pada arah yang sudah berubah. Perubahan pola oklusi adalah salah satu penyebab terjadinya kliking.
Penyebab lainnya adalah gerak mandibula yang berlebihan dan mendadak yang mengakibatkan pergerseran diskus atau clenching pada gigi yang berkepanjangan sehingga pembukaan berubah akibat kelelahan otot. Otot rahang yang memendek dan juga spasme dapat meningkatkan tekanan pada rahang dan menyebabkan bunyi klik. ${ }^{8}$ Kliking juga bisa terjadi secara intermiten pada remaja akibat gerak adaptasi waktu pertumbuhan sedang berlangsung. ${ }^{9}$

Hasil pengujian statistik dari penelitian ini dapat dilihat pada Tabel 4 yang menunjukkan adanya hubungan yang bermakna atau sifat signifikansi antara kebiasaan buruk postur tubuh dengan bunyi kliking pada sendi temporomandibula dengan tingkat keterkaitan sebesar 8,45\%. Berdasarkan penelitian etiologi, hubungan keduanya dapat diterangkan melalui fisiologis postur. Fisiologis postur, salah satunya dinilai dari keseimbangan sistem musculoskeletal pada sendi temporomandibula, posisi kepala, leher, dan tulang belakang. Keseimbangan tersebut dapat terganggu apabila terdapat kesalahan posisi normal. ${ }^{10}$ Hal ini dapat terjadi karena tubuh merupakan rangkaian muskuloskeletal dan multisendi yang terangkum dalam sistem musculoskeletal. ${ }^{1}$ Postur dapat mencerminkan keadaan sistem otot seperti pemendekan dan hiperaktivitas kepala, klavikula, otot sternokleidomastoideus akibat kebiasaan buruk postur yang berlangsung lama. ${ }^{11}$ Otot pada sistem stogmatognatik berhubungan denganototpadabagianservikal,menimbang bahwa sistem muskuloskeletal terdiri dari gabungan beberapa rangkaian otot yang saling berhubungan, maka bila terjadi 
gangguan pada salah satunya maka akan memperngaruhi pada bagian yang lain. ${ }^{12}$

Tabel 5 menunjukkan sifat signifikansi dan korelasi antara masing-masing kebiasaan buruk dengan bunyi kliking pada sendi temporomandibula, dimana terdapat hubungan yang signifikan yang kuat antara FHP dan kebiasaan duduk dengan menopang dagu dengan bunyi kliking pada sendi temporomandibular dan keterkaitan sebesar 40,83\%. Hal tersebut diperkuat dengan pernyataan Winarni pada tahun 2012 bahwa kepala yang terlalu ke depan yang disebabkan oleh karena pundak yang terlalu membungkuk dapat menimbulkan kelainan pada daerah kranioservikal dan sendi temporomandibula. Pada posisi FHP, posisi kondilus pada posisi istirahat mandibula rata-rata terletak $1 \mathrm{~mm}$ lebih ke posterior dibandingkan pada keadaan postur normal kepala. Pada posisi tersebut jaringan dapat mengalami microtrauma. ${ }^{14}$ Selain itu, kondilus akan menekan jaringan retrodiskal sehingga jaringan kehilangan elastisitasnya dan diskus dapat bergerak ke anterior sehingga terjadi kliking sebagai salah satu tanda gangguan pergeseran sendi dengan reduksi. ${ }^{15}$

Posisi kepala yang lebih condong ke depan menyebabkan rotasi pada bahu, elevasi dan abduksi pada skapula, depresi pada toraks dan forward displacement pada tubuh. ${ }^{16}$ Ketidakeseimbangan antara muscular dan skeletal dari postur kepala dan leher dapat berpengaruh terhadap tubuh, hal ini terjadi karena tubuh merupakan satu rangkaian skeletal dan multi-sendi yang terangkum dalamkompleksmusculoskeletal. Pergerakan setiap sendi merupakan interaksi dinamis dengan sendi lain dalam rangkaian. ${ }^{10}$ Abnormalitas spina servikal yang paling umum mempunyai dampak langsung terhadap regio kraniofasial adalah FHP. $^{17}$ Inflamasi berkepanjangan dari otototot paraspinal tidak hanya meningkatkan aktivitas otot-otot leher tetapi juga otot-otot mastikasi. $^{18}$

Kebiasaan duduk dengan menopang dagu memiliki signifikansi kuat dengan bunyi kliking sendi temporomandibular dan tingkat keterkaitan sebesar 13,96\%. Kebiasaan buruk seperti menopang dagu dapat menimbulkan tekanan yang berlebihan pada oklusal. ${ }^{1}$ Karena tekanan tersebut diterima berulang dan dalam jangka waktu yang lama diduga dapat menimbulkan gejala gangguan sendi temporomandibula dimana gejala kliking merupakan gejala yang paling sering menyertai disfungsi sendi temporomandibula. ${ }^{19}$

Duduk dengan menopang dagu menyebabkan ketidakseimbangan sagital, ketidakseimbangan koronal, kemiringan sudut pelvis dan lordosis yang signifikan secara statistik. Jadi hal tersebut bisa jadi menimbulkan masalah kesehatan. Dengan kata lain, ketidakseimbangan servikal akibat duduk dengan menopang dagu menyebabkan ketidakseimbangan tulang belakang. ${ }^{20}$ Duduk dengan menopang dagu biasanya disertai dengan keadaan tulang belakang yang membungkuk sehingga lama kelamaan dapat menyebabkan trauma tulang belakang. ${ }^{21}$ Selain itu, semakin lama durasi tekanan yang diterima pada dagu, maka semakin besar pula tekanan yang dapat dapat menimbulkan gejala temporomandibular disorders. ${ }^{1}$ Dalam masa pertumbuhan, kebiasaan yang tidak benar, seperti menopang dagu, dapat membuat bentuk wajah berubah. ${ }^{9}$ Beberapa contoh masalah yang bisa timbul karena kebiasaan yang salah adalah dagu menonjol, wajah asimetris, tak berdagu, rahang bersudut, dan sebagainya. Hal tersebut berpotensi menimbulkan gangguan pada sendi temporomandibular. ${ }^{13}$

Pada kebiasaan duduk membungkuk dan bermalas-malasan, kepala bersandar pada meja dalam keadaan duduk, membawa tas pada satu sisi, berdiri bertumpu pada satu kaki, dan kebiasaan tengkurap memiliki sifat signifikansi yang sedang. Kebiasaan duduk membungkukdan bermalas-malasan dengan bunyi kliking sendi temporomandibula memiliki sifat signifikansi yang sedang dengan tingkat keterkaitan sebesar 4,75\%. Duduk dengan posisi badan membungkuk 
sangat membebani struktur jaringan lunak vertebrapada diskus intervertebra, ligament dan otot. Duduk dalam posisi statis dan sikap tubuh yang kurang ergonomis seperti duduk dalam posisi membungkuk (kurang dari 90 derajat) dapat memicu kerja otot yang kuat dan lama tanpa cukup pemulihan. Pada sikap kerja statis terjadi kontraksi otot yang kuat dan lama tanpa cukup kesempatan pemulihan, dan aliran darah ke otot terhambat. Akibatnya, timbul rasa lelah dan nyeri pada otot tubuh..$^{22}$ Apabila otot-otot punggung tersebut menerima beban statis saat duduk jangka waktu lama, maka dapat menyebabkan keluhan berupa kerusakan pada sendi, ligamen, dan tendon keluhan hingga kerusakan inilah yang biasanya diistilahkan dengan keluhan muskulokeletal atau cidera pada sistem muskulokeletal. ${ }^{23}$

Kebiasaan duduk membungkuk dan bemalas-malasan cenderung menyebabkan posisi leher dan kepala lebih condong ke depan. Penyimpangan sikap tubuh tersebut bila dibiarkan dapat menyebabkan gangguan pada keseimbangan otot leher, otot pembuka dan penutup mulut, selanjutnya akan mempengaruhi sendi temporomandibula. ${ }^{24}$ Postur membungkuk cenderung membuat posisi leher lebih ke anterior dan terdapat adanya hiperaktivitas dari otot-otot mastikasi. ${ }^{8}$ Pasien gangguan sendi temporomandibua dengan disc displacement menunjukkan pada MRI adanya deviasi tulang belakang terutama pada servikal. ${ }^{25}$

Banyaknya variasi posisi duduk bebas tersebut disebabkan oleh ukuran meja dan kursi yang digunakan tidak ergonomis, sehingga seseorang merasa tidak nyaman. Ketidaksesuaian penggunaan meja dan kursi tentunya mempengaruhi kenyamanan dari seseorang dalam beraktivitas, yang ditunjukkan melalui variasi posisi duduk. Ketidaksesuaian tersebut menyebabkan seseorang duduk dengan posisi yang salah, yakni dengan posisi membungkuk dan posisi duduk bebas. Posisi duduk bebas adalah seperti berdiri, memutar badan ke kanan dengan posisi ketiak di sandaran kursi, membungkuk dengan pipi atau wajah yang menempel ke meja. ${ }^{26}$ Hubungan kebiasaan duduk dengan menyandarkan kepala pada meja dengan bunyi kliking sendi temporomandibula memiliki sifat signifikansi sedang dengan keterkaitan sebesar 8,68\%. Posisi tersebut akan membebani satu sisi rahang dengan beban statis, sehingga rahang terdorong dan menekan gigi pada oklusi lateral yang tak seimbang menyebabkan tekanan berterusan pada sisi yang terbebani. Selain itu, kepala kondilus menerima tekanan berkelanjutan pada diskus artikularis, dan jaringan retrodiskal yang mempunyai banyak vaskularisasi dan inervasi sehingga dapat memicu terjadinya gangguan pada sendi temporomandibula. Perubahan pola oklusi dan perpindahan posisi kondilus dapat menyebabkan terjadinya bunyi kliking pada sendi temporomandibula. ${ }^{27}$

Kebiasaan membawa tas pada satu sisi dengan bunyi kliking sendi temporomandibula memiliki sifat signifikansi yang sedang dengan keterkaitan sebesar 10,38\%. Membawa tas pada satu sisi dapat menyebabkan nyeri musculoskeletal dan berubahan lengkung tulang belakang. ${ }^{28}$ Membawa tas dengan satu sisi dalam jangka waktu yang lama dapat menyebabkan deviasi tulang belakang dimana tulang belakang lebih condong ke arah beban tas dan rotasi pada pelvis. Selain itu, posisi bahu menjadi tidak simetris dan otot leher menjadi tidak seimbang. ${ }^{29}$ Selain itu posisi tubuh yang asimetri dapat menyebabkan deviasi mandibula yang menjadi salah satu penyebab gangguan sendi temporomandibular. ${ }^{30}$

Kebiasaan berdiri bertumpu pada satu kaki dan bunyi kliking sendi temporomandibula memiliki korelasi dengan sifat signifikansi sedang dengan keterkaitan sebesar $12,98 \%$. Berdiri dengan bertumpu pada satu kaki menempatkan semua berat tubuh ke satu sisi dan memaksa tulang belakang melengkung ke satu sisi dan memberi tekanan pada area punggung bawah dan pinggul. Selain itu, lengkung vertebrae juga 
lebih condong ke sisi tumpuan kaki dan dapat terjadi rotasi pada pelvis. ${ }^{31}$ Kebiasaan beraktivitas dengan posisi tengkurap dengan bunyi kliking sendi temporomandibula memiliki sifat signifikansi sedang dengan keterkaitan sebesar 9,54\%. Posisi tersebut bisa menyebabkan subluksasi vertebra. Sublukasi dari servikal berpengaruh langsung terhadap sendi temporomandibula dan lumbar vertebrae. ${ }^{32}$ Posisi tulang belakang bisa mempengaruhi oklusi. ${ }^{33}$

Postur membungkuk saat berdiri, menunduk saat menggunakan ponsel, dan duduk dengan menyilang kaki tidak ada korelasi yang signifikan, tetapi kebiasaan tersebut dapat dinyatakan signifikan secara statistik apa bila $\alpha=0,07$. Punggung yang membungkuk juga cenderung membuat seseorang mencondongkan leher dan kepala ke depan, yang bisa menyebabkan ketegangan pada leher dan punggung bagian atas. $^{34}$ Komponen sistem muskuloskeletal pada tubuh sangat berkaitan satu sama lain, bila satu unit struktural terganggu maka keseimbangan sistem akan terganggu. kondisi patologis di satu area juga dapat mempengaruhi area lainnya. Secara khusus, otot rangka memainkan peran yang sangat penting, karena "rantai" anatomis dan fungsional yang kontinu terbentuk antara tengkorak, rahang bawah, tulang belakang, anggota badan dan panggul. ${ }^{35}$ Bila otot mengalami tekanan yang tinggi pada rantai mandibula, hyoid, vertebra, panggul dan anggota badan, akan disalurkan ke bagian tubuh lainnya. Sebagai konsekuensinya, tubuh kehilangan keadaan keseimbangan, sehingga menimbulkan mekanisme kompensasi, dimana terjadi tegangan otot pada bagian antagonis lainnya dari tubuh. ${ }^{36}$ Hal tersebut berpengaruh terhadap otototot mastikasi dan juga dapat menyebabkan gangguan pada sendi temporomandibular. ${ }^{37}$ Menunduk saat menggunakan ponsel membuat posisi rahang tidak dalam posisi optimal, otot rahang dan otot leher sulit untuk berfungsi dengan efisien. Semakin menunduk posisi kepala maka beban yang diterima leher akan semakin besar. Dengan beban yang meningkatleher akan mengalami ketegangan, terutama mengingat berapa banyak waktu yang habiskan untuk melihat handphone. ${ }^{8}$ Duduk dengan menyilangkan kaki dapat mengurangi kelelahan otot dengan mengurangi aktivitas otot pada otot perut internal dan eksternal perut, dan dapat menyesuaikan ketinggian kedua sisi panggul untuk keselarasan yang lebih baik jika kedua kaki individu memiliki panjang yang berbeda. Selain itu, hal ini dapat memberi stabilitas pada sendi sakro-iliaka individu yang memiliki ketidakstabilan di sendi tersebut dengan menghasilkan penambahan sendi pinggul. ${ }^{38}$ Namun, duduk menyilangkan kaki juga bisa menimbulkan banyak risiko bagi tubuh.

Duduk dengan menyilangkan kaki menyebabkan ketidakseimbangan pada otot abdominal internal dan oblique eksternal dan juga berdampak pada ketidaksimetrisan tulang belakang. ${ }^{39}$ Selain itu, duduk menyilang kaki juga dapat menyebabkan melemahnya vertebra lumbal atau berotasi. ${ }^{40}$ Hal tersebut berpotensi menyebabkan posisi bahu dan pinggul menjadi asimetri. Duduk dengan menyilang kaki juga dapat menyebabkan sakit pinggang dan punggung. Hal tersebut menunjukkan bahwa duduk dengan menyilang kaki tidak secara langsung dapat menyebabkan gangguan pada sendi temporomandibula. ${ }^{41}$

Tidur dengan bantal yang terlalu tinggi tidak memiliki korelasi yang signifikan secara statistik. Ketika berdiri tegak, kepala dan leher berada pada satu garis lurus bila dilihat dari depan dan terdapat lengkung leher bila dilihat dari samping. Posisi tersebut disebut juga neutral position. Neutral position juga harus dipertahankan dalam posisi tidur. Bila posisi bantal terlalu tinggi, maka posisi tersebut menyimpang dari posisi normal. Posisi tidur dengan bantal terlalu tinggi dapat merubah postur kepala, leher, dan tulang belakang. Selain itu otot-otot leher menjadi tidak rileks sehingga terdapat kemungkinan pegal pada leher. ${ }^{42}$ 


\section{SIMPULAN}

Terdapat hubungan yang signifikan antara kebiasaan buruk postur tubuh dengan bunyi kliking pada sendi temporomandibula dan pasien dengan kebiasaan buruk postur tubuh dapat mengalami gangguan pada sendi temporomandibula dengan gejala berupa bunyi kliking.

\section{DAFTAR PUSTAKA}

1. Okeson JP, Management of Temporomandibula Disorder and Oclussion, 4th ed. St. Louis: Elsevier; 2007. p. 8-10, 224-227.

2. Leonard, A., and Sabina M. The body posture and its imbalances in children and adolescents. Science, Movement and Health 2014; 14(2):354-359.

3. Winarti, TM., dan Rikmasari, R. Kebiasaan postur tubuh yang buruk yang mengganggu kesehatan sendi temporomandibula. Dentofasial 2011; 10(3):196-201.

4. Perinetti, G. Correlations between the stomatognathic system and body posture: biological or clinical implications? Clinics 2009. 64(2):77-78. Cited from https://doi.org/10.1590/ S1807-59322009000200002 (diakses Desember 2017).

5. Manfredini, D., B. Bucci, Marco, Nardini, L. G. The Diagnostic Process for Temporomandibular Disorders. Stomatologija, Baltic Dental and Maxillofacial Journal. 2007; 9:35-39.

6. Jerolimov, V. Temporomandibular disorders and orofacial pain. Medical Science 2009; 33:53-77.

7. Kumar, B. Poor posture and its causes. International Journal of Physical Education, Sports and Health 2016; 3(1):177-178.

8. Chiao, L., Guedes Z., Vieira M. Relationship between physical global posture and temporomandibular joint dysfunction: Masticatory muscle overactivity. Fisioterapia Brasil 2003; 4:341-347.
9. Kraus, S. Temporomandibula Disorders, Head and Orofacial Pain: Cervical Spine Considerations. Dent Clin North Am 2007; 51:161-193.

10. Norton, NS. Netter's Head and Neck Anatomy for Dentistry. China: Saunders Elsevier; 2007. p.27-58.

11. Tucker, J. Posture evaluations: forward head and forward shoulder. Dynamic Chiropractic 2010; 28(13):1-4.

12. Saito, ET., Akashi, PMH., Sacco, I. de CN. Global body posture evaluation in patients with temporomandibula joint disorder. Clinics 2009; 64(1):35-39. Cited from https://doi.org/10.1590/ S1807-59322009000100007 (diakses 14 Okt 2017).

13. Winarti, TM. Hubungan Forward Head Position dengan Gangguan Sendi Temporomandibula Berdasarkan Pengukuran Linear [Tesis]. Bandung: Universitas Padjadjaran; 2012. p. 45-53.

14. Berkovitz, BKB., Holland GR., Moxham BJ. Oral anatomy, histology, and embryology. 4th ed. Edinburgh: Mosby Elsevier; 2009. p. 62-68.

15. Ohmure, H., Miyawaki S., Nagata J., Ikeda K., Yamasaki K., Al-Kalaly A. Influence of forward head posture on condylar position. J Oral Rehabil 2008; 35(11):795-800.

16. Šidlauskas, M. Relationships between malocclusion, body posture, and nasopharyngeal pathology in preorthodontic children. Medical Science Monitor 2015; 21:1765-1773. Cited from https://doi.org/10.12659/ MSM.893395 (diakses 29 Januari 2018).

17. Hundekari, J., Chilwant, K., Vedpathak, S., Wadde, S. Does Alteration in Backpack Load Affects Posture of School Children?. IOSR Journal of Dental and Medical Sciences. 2013; 7(4): 71-75

18. Hu, JW., Yu XM., Vernon H., Sessle BJ. Excitatory effects on neck and jaw activity of inflammatory irritans injections into cervical paraspinal tissues. Craniofacial pain 2007; 55:243-350.

19. Chaudary, PK., Mohd TK, Sanjeev KV, 
Sandhya M, Syed NZ. Neuromuscular dentistry: Occlusal diseases and posture. Journal of Oral Biology and Craniofacial Research 2013; 3(3):146-150.

20. Hee, SW., Jong CO., Sung YW. Effects of asymmetric sitting on spinal balance J. Phys. Ther. Sci. 2016; 28:355-359.

21. Phimphasak, C., Swangnetr M., Puntumetakul R., Chatchawan U, Boucaut R. Effects of seated lumbar extension postures on spinal height and lumbar range of motion during prolonged sitting. Ergonomics 2015; 30:1-9.

22. Katarzyna MP, Barbara SW, Tomasz K, Anna S, Alicja K, Jarosław W, and Małgorzata KW. Prevalence of incorrect body posture in children and adolescents with overweight and obesity. Eur J Pediatr 2017; 176(5): 563-572.

23. Duffy, Vincent. Digital Human Modeling and Application in Health, Safety, Ergonomics, and Risk Management. 2013; p.159-160.

24. Carlsson, GH., and Magnusson T. Management of temporomandibular disease in general dental practice. Stockholm: Quintessence Pub. Inc; 2005 p. $50-51$.

25. D'Attilio M, Epifania E, Ciuffolo F, Salini V, Filippi MR, Dolci M, et al. Cervical lordosis angle measured on lateral cephalograms; findings in skeletal class II female subjects with and without TMD: A cross sectional study. Cranio 2004; 22:27-44.

26. Sugianto, PR. Hubungan ukuran meja dan kursi ergonomis dengan kenyamanan melalui posisi duduk murid taman kanak-kanak dewi sartika surabaya. BioKultur 2014; 3(1): 277-291.

27. Armijo-Olivo, S., Jara X., Castillo N., Alfonso L., Schilling A., Valenzuela E. Head and cervical posture in patients with temporomandibula disorders. J Orofac Pain 2011; 25:199-209.

28. Goodgold S, Mohr A, Samant A, Parke T, Burns T, Gardner L. Effects of backpack load and task demand on trunk forward lean: pilot findings on two boys. Work
2002; 18:213-220.

29. Smith, B, Ashton KM, Bohl D, Clarke RC, Metheny JB, Klassen S. Influence of carrying backpack on pelvic tilt, rotation, and obliquity in female collage students. Gait posture 2006; 23(3):263-267.

30. Ferro, F., Spinella P., Lama N. Transverse maxillary arch form and mandibular asymmetry in patients with posterior unilateral crossbite. Am J Orthod Dentofacial Orthop 2011; 140:828-838.

31. Lee, YJ., Park JH., Lee, SJ. Systematic Review of the Correlation Between Temporomandibular Disorder and Body Posture. J Acupunct Res 2017; 34(4):159-168

32. Lee, HJ., Park, SJ. The Relationship Between Forward Head Posture and Temporomandibula Disorders. Journal of medicine and life 2008; 9:161-167. Available from URL: http://www. ncbi.nlm.nih.gov/pubmed/ 19130800 (diakses 25 Jan 2018).

33. Tecco, S., Salini V., Teté S., Festa F. Effects of anterior cruciate ligament (ACL) injury on muscle activity of head, neck and trunk muscles: a cross-sectional evaluation. Cranio 2007; 25(3):177-85.

34. Ludwig, 0. Interrelationship between postural balance and body posture in children and adolescents. Journal of Physical Therapy Science 2017; 29(7):1154-1158. https://doi. org/10.1589/jpts.29.1154 (diakses 30 Des 2017).

35. Zeppa, I., Hurmerinta K., Kovero O., Nissinen M., Kononen M., Huggare J. Associations between thoracic kyphosis, head posture, and craniofacial morphology in young adults. Acta Odontol Scand 2000; 58:237-242.

36. Lippold, C., Danesh G., Hoppe G., Drerup B., Hackenberg L. Trunk inclination, pelvic tilt and pelvic rotation in relation to the craniofacial morphology in adults. Angle Orthod 2007; 77:29-35.

37. Hollenstein, J. Temporomandibular joint (TMJ) syndrome: Temporomandibular joint disorder; temporomandibular joint 
dysfunction; myofacial pain dysfunction syndrome. J Oral Rehabil 2006; 11(1):328.

38. Lim, JH., Lee, J., Koh, SE., Lee, In-Sik. Reliability and reproducibility of interapical distance assessment of the lateral deviation of vertebrae in scoliosis. J Phys Ther Sci 2015; 27:1199-1202.

39. Park, IS. Development of a system for measurement on sitting postural bias and biomechanical characteristics analysis of patients with pelvic asymmetry. Jeonbuk University: Disertation of master's degree; 2013. p. 51-53.
40. Kang, SY., Kim SH., Ahn SJ. A Comparison of pelvic, spine angle and buttock pressure in various cross-legged sitting postures. Phys Ther Korea 2012; 19:110.

41. Sahrmann, SA. Diagnosis and Treatment of Movement Impairment Syndrome. New York: Mosby; 2001. p. 61-64.

42. Humphires B.2010. Correct necksleeping ergonomics/correct pillow use. Available online at: https://redlandschiropractor. com/clients/8984/documents/Correct_ Sleeping.pdf (diakses 28 Februari 2018). 